\title{
A Study of Anti-Radiation Weaving Fabric with Plasma Corona Treatment
}

\author{
Valentinus Galih Vidia Putra ${ }^{1, a}$, Irwan ${ }^{2, b}$ Ichsan Purnama ${ }^{2, c}$ Juliany Ningsih \\ Mohamad $^{3, d}$, and Yusril Yusuf 4,e \\ ${ }^{1}$ Kementerian Perindustrian RI,Jakarta, Indonesia \\ ${ }^{2}$ Textile Engineering Department, Politeknik STTT Bandung, Bandung, Indonesia \\ ${ }^{3}$ Physics Department, Universitas Nusa Cendana, Kupang, Indonesia \\ ${ }^{4}$ Physics Department, Universitas Gadjah Mada, Yogyakarta, Indonesia
}

Email: a)valentinus@kemenperin.go.id-,b) irwan@stttekstil.ac.id, c)purnama@stttekstil.ac.id, d) ning_she@staf.undana.ac.id,e) yusril@ugm.ac.id

\begin{abstract}
In this research, Carbon black particles were applied on the woven fabric by the knife coating technique and pretreatment using plasma corona discharge to build-up conductive cotton-polyester (CVC 50\%) fabric electromagnetic shielding material. This paper describes the making of anti-radiation weaving fabric using plasma technology. The anti-radiation patch was developed by first modifying the textile fabric's surface using atmospheric pressure plasma technology using tip-cylinder electrode configuration. The plasma corona discharge was generated using high voltage electricity with asymmetrical electrodes (tip and cylinder). The treated weaving fabric using plasma was then coated with carbon black ink. This research indicates that an anti-radiation weaving fabric was successfully shielded electromagnetic radiation from an electronic device.
\end{abstract}

Keywords: Anti-radiation, corona Discharge Plasma, weaving fabric, tip-cylinder electrode

\section{INTRODUCTION}

The application of physics in various fields of textiles has been widely implemented. Some researchers ${ }^{[1-24]}$ have shown the application of physics in the case of textiles both in computational modeling and simulation and experimental research. Putra et al. ${ }^{[22]}$ and Cheng L, et al. ${ }^{[8]}$ have successfully developed conductive fabrics as anti-radiation material for electromagnetic waves. Some researchers ${ }^{[1-6]}$ have studied textile materials with the topic of fine coating engineering studies with the plasma method or conventional methods on textile materials. The application of physics in the field of fashion starts from the millennial generation and generation $Z$, which has an age range of 19-30 years in metropolitan cities, i.e., Bandung and Jakarta, preferring to use modern electronic device (such as smartphone, laptop, or tablet) technology in daily activities including sports activities. They almost always use electronic devices to listen to music with smartphones or tablets stored in their pocket [17${ }^{18]}$. Several studies ${ }^{[2,3,4,8,12-16]}$ showed that electronic devices such as computers, smartphones, laptops or tablets, have electromagnetic radiation that can harm or negatively affect the user's body. Data released by the German federation that 10 out of 16 electronic devices (such as smartphones, laptops, or tablets)s from one of the manufacturers have higher radiation levels than others. Based on this generation's behavior and the effects caused by electronic device (such as smartphone, laptop, or tablet) radiation, this research aims to manufacture antiradiation patch fabric affixed to one side of the body unisex sportswear pocket. Unisex 
characteristics are adapted to the behavior of millennial and $\mathrm{Z}$ generations who want free expression without restrictions.

Making this patch fabric uses technology that utilizes applied physics in the process. One physics application is the use of tip-cylinder corona plasma technology to enhance the coating process to make anti-radiation patch fabrics. According to Shishoo ${ }^{[1]}$, plasma technology is the fourth material after solid, liquid, and gas. Plasma is defined as an ionized gas of free particle particles. Plasma technology was introduced in the 1960s and has been widely applied in the textile and microelectronic industries. The application of physics in various industry fields, especially textiles, has been widely used or applied in theoretical and experimental modeling. Some industries such as plastics, polymers, textiles, metals, and ceramics use plasma technology to modify surface properties. The advantages of using plasma technology include increasing water absorption, increasing adhesion forces, sterilization, etc. The results showed that the effect of modification of the superficial surface would change the material's mechanical properties as a whole: mass loss, fabric tenacity and surface roughness, and increased adhesive force. Some examples of plasma technology application are the application of plasma technology in modifying the nanostructures of the cloth nanostructures, textile fabrics' wettability, modification of the surface tension of fabrics, waste treatment, etc., which several researchers have investigated. ${ }^{[18-24]}$. Shishoo ${ }^{[1]}$ showed that $\mathrm{O} 2, \mathrm{~N} 2$, and Argon (Ar) gases change the fabric's properties to be more hydrophilic (easier to absorb liquid) while C2F6, SF6's gases will change the fabric's properties to hydrophobic (difficult to absorb liquids). Based on the literature review that we described, many studies did not observe the application of corona discharged plasma technology to improve wettability and adhesive properties on several fabrics in the coating process on the fabrication of anti-radiation fabric. This paper describes making anti-radiation patch fabric by modifying the fabric surface using a tip-cylinder corona discharged plasma technology and coating the fabric with carbon-based conductive ink. In this research, the fabric used was cotton-polyester (CVC) fabric with a density of $239 \mathrm{gr} / \mathrm{m} 2$. High-quality carbon conductive ink mixed with water-based acrylic adhesives, making it easy to clean. Carbon ink was chosen because of its conductive properties, which can block the electromagnetic waves emitted by electronic devices (such as smartphones, laptops, or tablets). In this study, the main component of conductive ink used was carbon ink in the form of a fine powder that has been mixed with water and then added acrylic adhesive so that it was a thick and sticky liquid. The carbon ink was then used to coat the fabric. After drying and curing, the carbonink could stick permanently to the fabric surface. This layer serves to protect radiofrequency radiation emitted by an electronic device; hence the body that was in direct contact with an electronic device was protected from high radiation.

\section{METHODS}

Anti-radiation patch cotton-polyester (CVC 50\%) fabric was made in several stages. The first step was to modify the fabric surface with plasma technology using a plasma generator explicitly made for this experiment (Figure 1). A cotton-polyester (CVC 50\%) fabric was placed inside the plasma device above a solid cylinder (cylinder) under a pointed electrode (tip). Then the fabric surface was modified with a discharged plasma treatment for 2 minutes and 4 minutes with an input voltage of 50V AC. Discharged plasma was generated using a high DC voltage of $3 \mathrm{kV}$ with a room temperature of $27-28^{\circ} \mathrm{C}$ and a room gas medium $\left(\mathrm{O}_{2}\right)$. The cotton-polyester (CVC) fabric given plasma radiation exposure was done by water absorption test using a drop test to determine the length of time it takes the fabric to absorb water perfectly. The drop test was done with water that has been mixed with syrup so that it could become a liquid. The test drops were divided into three processes: the first was a 
cotton-polyester fabric measuring $5 \times 8 \mathrm{~cm}^{2}$ without plasma treatment, fabric exposed to plasma radiation for 2 minutes, and fabric exposed to plasma radiation for 4 minutes. All the drops were recorded and analyzed, and it was found that the optimal plasma treatment time was 4 minutes. Then the plasma process is carried out for a patched fabric measuring $15 \times 16$ $\mathrm{cm}^{2}$ to modify the surface ideally. After coating the fabric with conductive ink, the antiradiation patch fabric was dried for approximately 24 hours at room temperature. Antielectromagnetic radiation test on cellphones was carried out using a radiation measuring instrument, namely the electromagnetic radiation tester. The electromagnetic radiation test's measurement results are in the form of an electric field value $(\mathrm{E})$ in a unit of $(\mathrm{V} / \mathrm{m})$ and a magnetic field value $(\mathrm{H})$ in the unit of $(\mu \mathrm{T})$. When the radiation measuring instrument's distance was close to the radiation source, the resulting value was more significant than the distance of the radiation measuring instrument far from the radiation source. An electromagnetic radiation test was carried out at the cell phone radiation source because the planned application of this research's fabric will be used on fabrics that can store cell phones, such as pockets. Tests were carried out by placing the radiation source on a flat cylinder, then the radiation measuring instrument (radiation tester) was closer to the radiation source with a specified distance. In this study, the distance measured was $0 \mathrm{~cm}, 0.5 \mathrm{~cm}$, and $1 \mathrm{~cm}$.

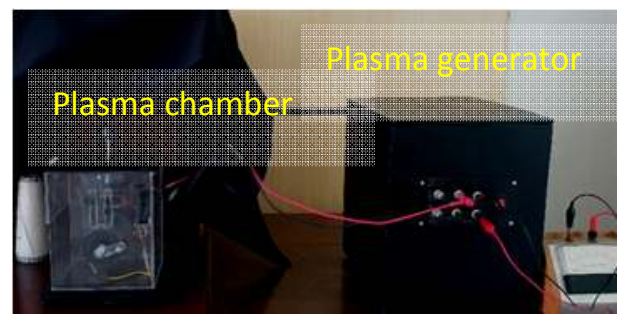

Figure 1. Plasma Corona Generator

\section{RESULTS AND DISCUSSIONS}

\section{The Analysis of Particles in Plasma Generator}

The generation of particles in plasma radiation with a plasma generator in the form of asymmetrical electrodes can be regulated through visual analysis and the measurement of $\mathrm{AC}$ input voltage and DC output voltage. Corona discharge plasma in this study was generated using asymmetrical electrode pairs, namely three tip electrodes (as an anode electrode) and solid cylinders (as cathode electrodes). Plasma radiation discharge occurred in areas with high electrical potential around positive electrodes or taper electrodes (anodes) that had a sharp geometric shape (in the case of taper electrodes are bolts) compared to solid cylindrical electrodes (cathodes). According to Rauscher, Perucca, Buyle ${ }^{[6]}$, a significant increase in current indicated an increase in electron density and the formation of positive ions in the space between the electrodes. This increase was due to the more straightforward ionization process. When the density of electrons and ions had a relatively equal value, a plasma region was formed in the taper bolt electrode area (anode). The plasma region formed was a nonuniform plasma region or non-uniform plasma due to the inequality between electron mass density and ionic mass density in the area between the electrodes. Electron movement was measured using a high voltage multi-tester in which the direction of the electron movement was opposed to current and electric field $\mathrm{E}$. The plasma region that began to form due to the high voltage potential of electricity can be seen by the appearance of blue electromagnetic waves under the anode, as shown in Figure 2. The ionized gas (plasma) in the plasma zone's ionization zone moved towards the negative cylindrical negative electrode (cathode) through 
a drift region. The flow of these blue ions caused an ion current called a unipolar saturation current. The flow of positive ions carried molecules and gas atoms in the area between the bolt electrode and the solid cylinder. This positive ion flow also contained reactive oxygen gas molecules, which changed the fabric's surface properties by modifying the fabric's roughness by the collision of positive ions resulting from ionization on the surface of the cotton-polyester fabric.

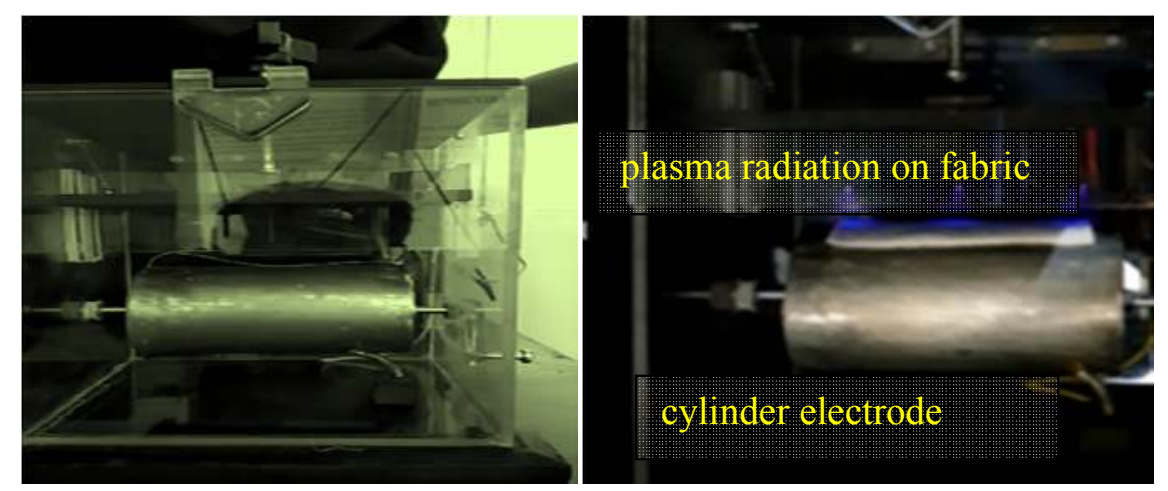

Figure 2. Positive ion flow (Blue Color)

\section{The Analysis of Modification of Anti-radiation Fabrics}

The wettability test was carried out on a cotton-polyester fabric with a density of surface 239 gr $/ \mathrm{m}^{2}$ measuring $5 \times 8 \mathrm{~cm}^{2}$ to be modified through plasma treatment for 2 minutes and 4 minutes with room air temperature. The wettability test was conducted at the beginning of the process to determine the absorption of fabric after the plasma treatment process. The measurement of the wettability test in time can be seen in Figure 3 and Table 1. The figure shows the difference in the absorption time of cotton-polyester fabric that has not been exposed to plasma radiation after exposure to plasma radiation within 2 minutes and 4 minutes. Fabric that has not been exposed to plasma radiation takes 2.42 minutes (162 seconds) to absorb droplets of water correctly. In comparison, fabric exposed to plasma radiation for 2 minutes takes 1 minute 45 seconds (105 seconds) to absorb the water, and the fabric given exposure to plasma radiation for 4 minutes absorbed the water with an absorption time of 12.89 seconds. Based on these results, the plasma treatment time of 4 minutes was the optimal time to modify the anti-radiation patch fabric's surface.

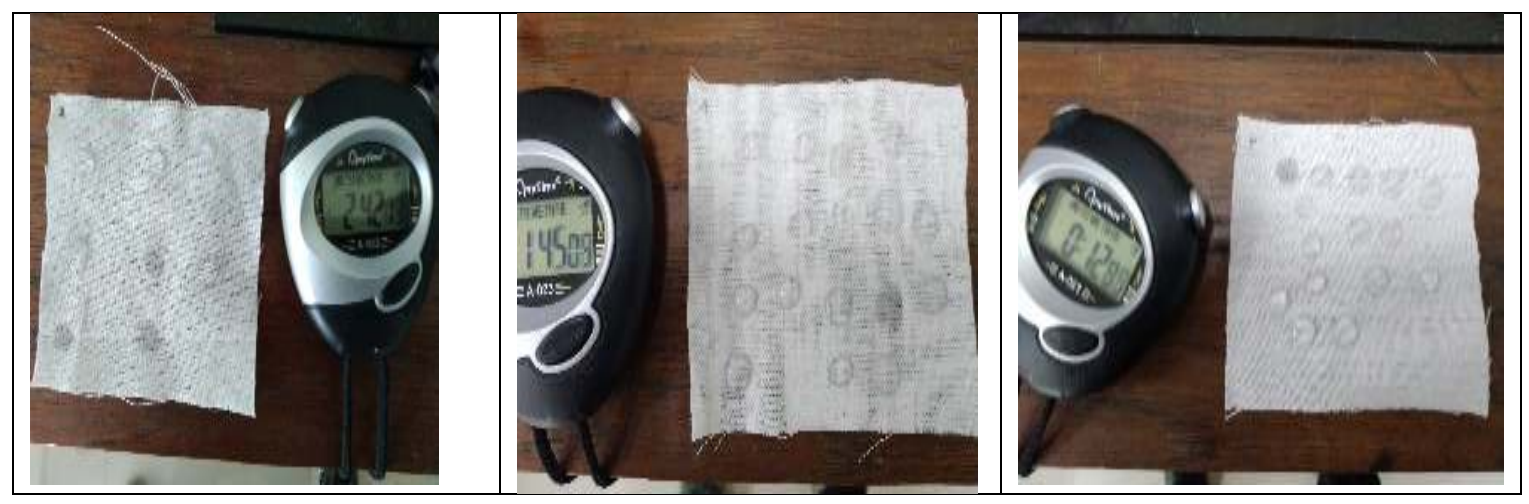

Figure 3. Syrup Liquid Test: a) on fabrics without exposure to plasma radiation, b) fabrics with plasma radiation exposure for 2 minutes, c) fabrics with exposure to plasma radiation for 4 minutes 
Tabel 1. The relationship between exposure time and absorbency time

\begin{tabular}{ccc}
\hline $\begin{array}{c}\text { Time of exposure } \\
\text { (minute) }\end{array}$ & Output voltage DC (kV) & $\begin{array}{c}\text { Average of absorbency time } \\
\text { (seconds) }\end{array}$ \\
\hline 0 & 3 & 162 \\
2 & 3 & 105 \\
4 & 3 & 12.89 \\
\hline
\end{tabular}

After the test drops, the anti-radiation patch fabric was produced by coating it using conductive ink. The fabric used had an area of $15 \times 16 \mathrm{~cm} 2$. A conductive fabric exposed to plasma radiation was placed on a flat surface to be coated with a conductive ink using a knife coating method so that the conductive ink was uniform on the surface (Figure 4). After being coated, the fabric was dried for 24 hours at room temperature and humidity.

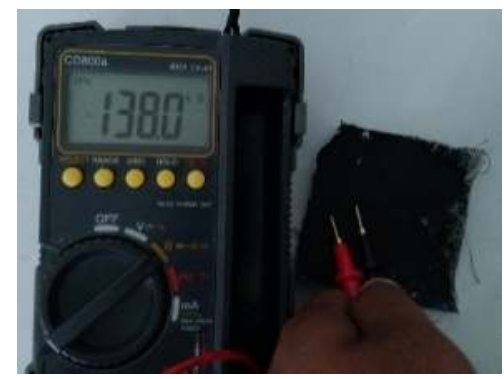

Figure 4. Conductive fabric that has been coated

After drying completely, the level of transmittance of electromagnetic waves emitted by the electronic device (such as a smartphone, laptop, or tablet) was carried out using the BENETECH GM3120 radiation test device. Tests were carried out one time each on a certain with an ordinary fabric and anti-radiation patch fabric. The results of this measurement are seen in Figure 5.
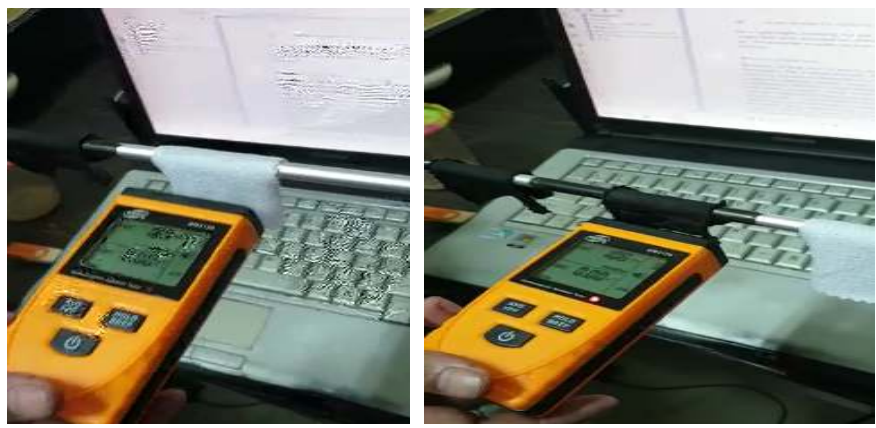

Figure 5. (a) Measuring results of electromagnetic waves before coated with anti-radiation patch fabric (b) Measuring results of electromagnetic waves after being coated with anti-radiation patch fabrics

Based on the measurement of the electromagnetic wave transmittance level emitted by an electronic device (such as a laptop) and testing using the BENETECH GM3120 radiation test instrument, the results showed that the presence of conductive fabric in Figure 5 could reduce the transmittance rate of electromagnetic waves. An anti-electromagnetic radiation test on the laptop was carried out using a radiation measuring instrument, i.e., the electromagnetic radiation tester. The electromagnetic radiation test's measurement results were in the form of an electric field value (E) in a unit of $\mathrm{V} / \mathrm{m}$ and a magnetic field value $(\mathrm{H})$ in a unit of $\mu \mathrm{T}$. Tests were carried out by placing the radiation source on a flat cylinder, then the radiation measuring instrument (radiation tester) was closer to the radiation source with a specified 
distance. In this study, the distances of the sensor and fabric measured were $0 \mathrm{~cm}$ and $0.5 \mathrm{~cm}$. In this test, three types of testing were carried out, i.e. (1) Testing without barriers, explicitly testing direct electromagnetic radiation with radiation tester measuring devices without any blocks; (2) Testing using a non-conductive cotton-polyester (CVC) fabric barrier with a composition of cotton yarn and polyester yarn; (3) Testing using conductive cotton-polyester (CVC) fabric, with the composition of CVC yarn and conductive ink. The purpose of these three tests was to determine the extent of the influence of conductive cotton-polyester fabrics on electromagnetic radiation. The results of these three tests can be seen in Table 2 .

Table 2. Results of cell phone electromagnetic radiation test results

\begin{tabular}{|c|c|c|c|c|c|}
\hline Kind of experiment & $\begin{array}{c}\text { Distance } \\
\text { the sensor } \\
\text { from } \\
\text { fabric } \\
\text { (cm) }\end{array}$ & $\begin{array}{c}E \\
\text { field } \\
(V / m)\end{array}$ & $\begin{array}{l}\text { Deviation } \\
\text { Standard }\end{array}$ & $\begin{array}{c}\text { H } \\
\text { Field } \\
(\mu \mathrm{T})\end{array}$ & $\begin{array}{c}\text { Deviation } \\
\text { Standard } \\
\text { (s) }\end{array}$ \\
\hline \multirow[t]{2}{*}{$\begin{array}{c}\text { Source of radiation } \\
\text { without fabric (no. 1) }\end{array}$} & 0 & 389 & 3.32 & 1.31 & 0.1 \\
\hline & 0.5 & 141 & 3.01 & 0.65 & 0.01 \\
\hline \multirow[t]{2}{*}{$\begin{array}{l}\text { Nonconductive fabric } \\
\text { (no. 2) }\end{array}$} & 0 & 356 & 3.10 & 1.26 & 0.02 \\
\hline & 0.5 & 121 & 1.50 & 0.35 & 0.01 \\
\hline \multirow[t]{2}{*}{ Conductive fabric (no. 3) } & 0 & 0 & 0 & 0.01 & 0.01 \\
\hline & 0.5 & 0 & 0 & 0.01 & 0.01 \\
\hline
\end{tabular}

The results of the radiation waves test for the E field at the distance of the fabric to the sensor for $0 \mathrm{~cm}$ and $0.5 \mathrm{~cm}$ can be shown in Figure 6

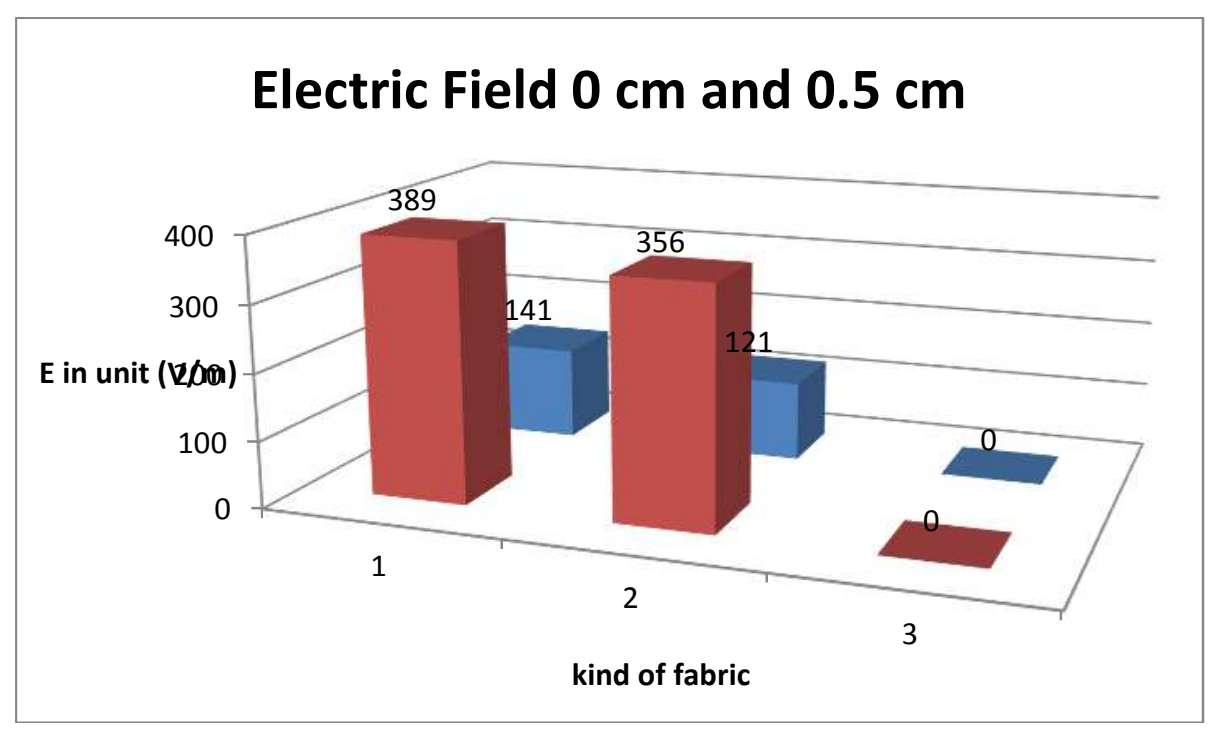

Figure 6. Comparison of $E$ field for a distance of a) $0 \mathrm{~cm}$ for kind of experiment on no.1, no. 2, and no. 3 (red color), and b) $0.5 \mathrm{~cm}$ for kind of experiment on no. 1, no. 2, and no. 3 (blue color) 
The results of the radiation waves test for the $\mathrm{H}$ field at the distance of the fabric to the sensor for $0 \mathrm{~cm}$ and $0.5 \mathrm{~cm}$ can be shown in Figure 7

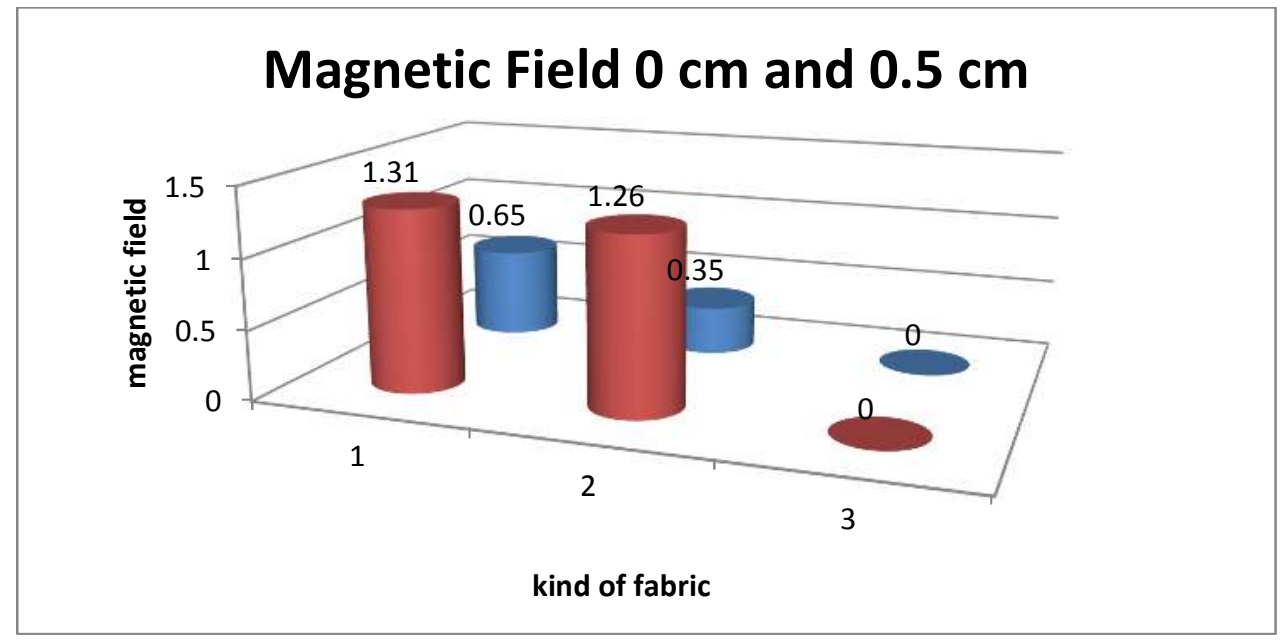

Figure 8. Comparison of $\mathrm{H}$ field for a distance of a) $0 \mathrm{~cm}$ for kind of experiment on no.1, no. 2, and no. 3 (red color), and b) $0.5 \mathrm{~cm}$ for kind of experiment on no.1, no. 2, and no. 3 (blue color)

This research has proven that the application of plasma technology in modifying the nanostructures of fabric nanostructures, textile fabrics' wettability, and the adhesiveness of material was studied by several researchers ${ }^{[18-24]}$. The process of generating plasma species in the plasma chamber Figure 2 can be explained as follows: when a particle (A) is subjected to electrons coming from the cylindrical electrode, there can be an occurrence of the ionization process $\mathrm{A}+\mathrm{e} \rightarrow \mathrm{A}^{+}+\mathrm{e}+\mathrm{e}$, in the process recombination can occur after ionization processes such as $\mathrm{A}^{+}+\mathrm{e}+\mathrm{e} \rightarrow \mathrm{A}^{*}+\mathrm{e} \rightarrow \mathrm{A}+\mathrm{e}$ where $\mathrm{A}$ is a neutral particle, $\mathrm{A}^{+}$is a positive ion particle losing electrons and $\mathrm{A} *$ is a radical particle gaining electrons close to it [6]. According to Rauscher, Perucca, Buyle ${ }^{[6]}$, a significant increase in current indicates an increase in electron density and the formation of positive ions in the space between the electrodes. Based on the results, the increase in electron density was due to the easier ionization process. When the density of electrons and ions had a relatively equal value, a plasma region was formed in the taper bolt electrode area (anode). In this study, the plasma region formed was a non-uniform plasma region or non-uniform plasma due to the inequality between electron mass density and ionic mass density in the area between the electrodes.

\section{CONCLUSIONS}

It has been explained the method to develop an electronic device anti-radiation patch fabric that can be attached to a unisex sportswear pocket using tip-cylinder electromagnetic plasma treatment. The fabric patch's initial results succeeded in reducing almost $100 \%$ of electronic device radiation in an active state.

\section{ACKNOWLEDGEMENT}

Thank you to the research funders of the Polytechnic of STTT Bandung and Nusa Cendana University, and to colleagues who helped research and discuss. 


\section{REFERENCES}

1 Shishoo. 2007. Plasma Technology For Textile. Woodhead Publishing, Cambridge.

2 Cheng, L., Zhang, T., Guo, M., Li, J., Wang, S., \& Tang, H. 2015. Electromagnetic shielding effectiveness and mathematical model of stainless steel composite fabric. The Journal of The Textile Institute, Vol. 106, No. 6, pp. 577-586.

3 Hwang, P. W., Chen. A. P., Lou, C. W., \& Lin, J. H. 2014. Electromagnetic shielding effectiveness and functions of stainless steel/bamboo charcoal conductive fabrics. Journal of Industrial Textiles, Vol. 44, No.3, pp. 477-494.

4 Balodis, V., Brūmelis, G., Kalviškis, K., Nikodemus, O., Tjarve, D., \& Znotiņa, V. 1896. Does the Skrunda Radio Location Station diminish the radial growth of pine trees? Science of the Total Environment, Vol. 180, No. 1, pp. 57-64.

5 Sjaifudin., Widodo, M., Muhlisin, Z., \& Nur, M. 2014. Modifikasi Permukaan Bahan Tekstil Dengan Plasma Lucutan Korona, Prosiding Seminar Nasional Tekstil, Hal. 1-22.

6 Rauscher., Perucca., \& Buyle. 2010. Plasma Technology For Hyperfunctionals Surfaces, Wiley-VCH, Weinheim.

7 Lawrence, C. A. 2003, Fundamentals of Spun Yarn Technology, CRC Press, New York.

8 Gherardini, L., Ciuti, G., Tognarelli, S., Cinti. C. 2014. Searching for the perfect wave: the effect of radiofrequency electromagnetic fields on cells, International Journal of Molecular Sciences, Vol. 15, No. 4, pp. 5366-5387.

9 Putra, V.G.V., Maruto, G., \& Rosyid, M.F. 2017. New theoretical modeling for predicting yarn angle on OE yarn influenced by fibre movement on torus coordinate based on classical mechanics approach. Indian Journal of Fibre and Textile Research, Vol. 42. pp. 359-363.

10 Lieberman, M., \& Lichtenberg, A. 1994. Principles of Plasma Discharges and Materials Processing, New York: John Wiley and Sons.

11 Boonchoat Paosawatyanyong, \& Satreerat Hodak. 2010. Hydrophobic and Hydrophilic Surface Nano-Modification of PET Fabric by Plasma Process. Journal of Nanoscience and Nanotechnology, Vol. 10, pp. 7050-7054.

12 Safarova, V., Tunak, M., Truhlar, M., Militky, J. 2016. A new method and apparatus for evaluating the electromagnetic shielding effectiveness of textiles. Text. Res. J., Vol. 86, pp. $44-56$

13 Chen, H.C., Lee, K.C., Lin, J.H., \& Koch, M. 2007. Comparison of electromagnetic shielding effectiveness properties of diverse conductive textiles via various measurement techniques. J. Mater. Process. Techol, Vol. 192, pp. 549-554.

14 Safarova, V., \& Militky, J. 2012. Comparison of methods for evaluating the electromagnetic shielding of textiles. Fibers Text, Vol. 19, pp. 50-55.

15 Avloni, J., Lau, R., Ouyang, M., Florio, L., Henn, A.R., \& Sparavigna, A. 2007. Shielding Effectiveness Evaluation of Metallized and Polypyrrole-Coated Fabrics. $J$. Thermoplast. Comp. Mater, Vol. 20, pp. 241-254.

16 Ozen, M.S., Usta, I., Yuksek, M., Sancak, E., Soin, N. 2018. Investigation of the Electromagnetic Shielding Effectiveness of Needle Punched Nonwoven Fabrics Produced from Stainless Steel and Carbon Fibres. Fibers Text. East. Eur, Vol. 26, pp. 94-100.

17 MarComm, M. 2018. MILLENIALS. Jakarta: Fantasious x Loveable.

18 Stillman, D. S. 2018. Generasi Z: Memahami Karakter Generasi Baru yang Akan Mengubah Dunia Kerja. Jakarta: PT Gramedia Pustaka Utama.

19 Putra, V. G., \& Wijayono, A. 2019. Suatu Studi Awal Modifikasi Sifat Pembasahan Pada Permukaan KainTekstil Poliester 100\% Menggunakan Teknologi Plasma Pijar Korona. Prosiding Seminar Nasional Fisika (E-Journal), Hal. 15-20. 
20 Putra, V. G., Mohamad, J. N., \& Yusuf, Y. 2020. Study Of Surface Tension Properties Looked On Contact Angle Value On 100\% Nylon Textile Fabric Using Corona Discharge Plasma Technology. Wahana Fisika, pp. 10-17.

21 Putra, V. G., Mohamad, J., \& Wijayono, A. 2020. Efek Modifikasi Plasma Untuk Meningkatkan Sifat Tahan Api Dari Kain Katun. Jurnal Dinamika Penelitian Industri, Vol. 31, No. 1, Hal. 59-70.

22 Putra, V., Fitri, A., Purnama, I., \& Mohamad, J. 2020. Prototipe Pakaian Anti Radiasi Unisex Sportswear. Jurnal Kumparan Fisika, Hal. 19-24.

23 Putra, V., Mohamad, J., \& Yusuf, Y. 2020. Penerapan Gelombang Plasma dalam Mengurangi Kadar Chemical Oxyegen Demand. Jurnal Ilmu Fisika, Hal. 60-69.

24 Murti, W., \& Putra, V. G. 2020. Studi Pengaruh Perlakuan Plasma TerhadapSifat Material AntiBakteri Kain Kassa Menggunakan Minyak Atsiri (Zingiber Officinale Rosc). Jurnal Teori dan Aplikasi Fisika, Hal. 69-76. 